\title{
Clinical Course, Prognosis, and Causes of Death in Mixed Connective Tissue Disease
}

\author{
Agota Hajas, Peter Szodoray, Britt Nakken, Janos Gaal, Eva Zöld, Renata Laczik, \\ Nora Demeter, Gabor Nagy, Zoltan Szekanecz, Margit Zeher, Gyula Szegedi, and Edit Bodolay
}

\begin{abstract}
Objective. To study the survival rate and prognostic indicators of mixed connective tissue disease (MCTD) in a Hungarian population.

Methods. Two hundred eighty patients with MCTD diagnosed between 1979 and 2011 were followed prospectively. Clinical features, autoantibodies, and mortality data were assessed. Prognostic factors for survival were investigated and survival was calculated from the time of the diagnosis by Kaplan-Meier method.

Results. A total of 22 of 280 patients died: the causes of death were pulmonary arterial hypertension (PAH) in 9 patients, thrombotic thrombocytopenic purpura in 3, infections in 3 , and cardiovascular events in 7. The 5,10, and 15-year survival rates after the diagnosis was established were 98\%, 96\%, and $88 \%$, respectively. The deceased patients were younger at the diagnosis of MCTD compared to patients who survived $(35.5 \pm 10.4$ vs $41.8 \pm 10.7 \mathrm{yrs} ; \mathrm{p}<0.03)$, while there was no difference in the duration of the disease $(\mathrm{p}=0.835)$. Our cohort study showed that the presence of cardiovascular events $(p<0.0001)$, esophageal hypomotility $(p=0.04)$, serositis $(p<0.001)$, secondary antiphospholipid syndrome $(\mathrm{p}=0.039)$, and malignancy $(\mathrm{p}<0.001)$ was significantly higher in the deceased patients with MCTD. The presence of anticardiolipin $(p=0.019)$, anti- $\beta_{2}$-glycoprotein $\mathrm{I}(\mathrm{p}=0.002)$, and antiendothelial cell antibodies $(\mathrm{p}=0.002)$ increased the risk of mortality.

Conclusion. Overall, PAH remained the leading cause of death in patients with MCTD. The prevalence of cardiovascular morbidity and mortality, malignancy, and thrombotic events increased during the disease course of MCTD. The presence of antiphospholipid antibodies raised the risk of mortality. (First Release May 1 2013; J Rheumatol 2013;40:1134-42; doi:10.3899/jrheum.121272)
\end{abstract}

Key Indexing Terms: $\begin{array}{llrl}\text { MIXED CONNECTIVE TISSUE DISEASE } & \text { CLINICAL COURSE } & \text { PROGNOSIS } \\ \text { SURVIVAL } & \text { ANTIPHOSPHOLIPID SYNDROME } & \text { CARDIOVASCULAR EVENTS }\end{array}$

In the early 1970s a new disease was added to the family of connective tissue diseases, denoted mixed connective tissue disease (MCTD). These patients showed a number of shared clinical features including Raynaud phenomenon (RP), arthritis, puffy hands, abnormal esophageal motility, lymphadenopathy, and myositis. Sharp, et al described MCTD as an "apparently distinct rheumatic disease syndrome associated with high titer of antibody to an extractable nuclear antigen"1,2.

From the Division of Clinical Immunology, Department of Medicine, Medical and Health Science Centre, University of Debrecen, Debrecen, Hungary; Institute of Immunology, Rikshospitalet, University of Oslo, Oslo, Norway; Division of Rheumatology, Kenezy Hospital, Debrecen, Hungary; Institute of Immunology, Medical and Health Science Centre, University of Debrecen, Debrecen, Hungary; Department of Radiology, University of Pécs, Medical School, Pécs, Hungary; and Department of Rheumatology, Medical and Health Science Centre, University of Debrecen, Debrecen, Hungary.

Supported by research grant numbers ETT 260/2009 and ETT 197-05/2010 from the Ministry of Health, Republic of Hungary.

A. Hajas, MD, Division of Clinical Immunology, Department of Medicine, Medical and Health Science Centre, University of Debrecen; P. Szodoray, $M D, P h D, D S c ; B$. Nakken, $M D, P h D$, Institute of Immunology, Rikshospitalet, University of Oslo; J. Gaal, MD, PhD, Division of Rheumatology, Kenezy Hospital; E. Zöld, MD, PhD, Division of Clinical
During the next 20 years many studies were published reporting contradictory views about the nature of MCTD, and the original description required considerable modifications. Organ involvement is often more extensive than was previously thought; neurological expression and pulmonary disease, erosive arthritis, various skin signs, and vasculitis have been added to the clinical picture $3,4,5,6,7,8,9,10,11,12$, $13,14,15$. In our previous study we reported that MCTD has heterogeneous clinical and serological characteristics, with 
varying disease course ${ }^{16}$. Very little is known about the mortality, morbidity, and factors influencing the disease outcome in patients with MCTD. In 1987, Miyawaki and Onodera reported 45 patients with MCTD, for whom 5-year survival was $90.5 \%$, while the 10 -year survival was $82.1 \%{ }^{17}$.

Earlier reports showed that the leading cause of death in MCTD is pulmonary arterial hypertension (PAH), with obliterative vasculopathy $18,19,20,21,22,23$. The high number of deaths in MCTD is also associated with involvement of internal organs related to the disease, such as lung and cerebrovascular and renal disease, especially in childhood $^{24,25}$.

Recently, thrombotic events, cardiovascular damage, and tumors were reported in patients with MCTD. We analyzed the survival, clinical features, and autoantibodies associated with mortality, the causes of death, and prognostic factors in 280 patients with MCTD who were followed at our division during a 30 -year period.

\section{MATERIALS AND METHODS}

We recruited 280 consecutive patients with MCTD who were followed at the Division of Clinical Immunology, University of Debrecen, between 1979 and 2011. The mean age of the total 280 patients ( 259 female, 21 male) at the time of the investigation was $53.1 \pm 12.6$ years (range 19-78 yrs). The mean followup of the disease was $13.1 \pm 7.5$ years (range 1-33 yrs).

The classification criteria for MCTD were those described by Alarcon-Segovia and Villarreal, including RP, swelling of the hands with a spindle-like swelling of the fingers, sclerodactyly, synovitis, myositis, and the presence of anti-U1-RNP autoantibodies in the patients' sera ${ }^{26}$.

The investigation protocol was in compliance with Good Clinical Practices, the Declaration of Helsinki, and the guidelines of the Medical and Health Science Centre of the University of Debrecen. The investigations were approved by the Regional and Institutional Ethics Committee, Medical and Health Science Centre, University of Debrecen.

Laboratory and immunological studies. All patients underwent a complete blood count, kidney and liver function tests, creatine phosphokinase (CK), and urinalysis.

Antinuclear antibodies (ANA) were detected on human epithelial cell line 2 substrate (HEp-2 cells) by indirect immunofluorescence. ANA was considered positive when titers were $>1: 64$.

Serum concentrations of autoantibodies were analyzed by commercial ELISA: anti-U1-RNP (Pharmacia and Upjohn); anti-SSA, anti-SSB, anti-Jo1, anti-Sc170 (Hycor Biomedical); anti-dsDNA, anticardiolipin (aCL $\mathrm{IgG}, \mathrm{IgM}, \mathrm{IgA}$ ), anti- $\beta_{2}$-glycoprotein I (anti- $\beta_{2}$-GPI IgG, IgM, IgA; Orgentec); and anticitrullinated protein antibody (ACPA; Immunoscan CCPlus, Euro-Diagnostica). Cutoff values were $5 \mathrm{U} / \mathrm{ml}$ for anti-U1-RNP; $10 \mathrm{U} / \mathrm{ml}$ for anti-SSA, anti-SSB, anti-Jo1, anti-Scl70; $20 \mathrm{U} / \mathrm{ml}$ for anti-dsDNA; $10 \mathrm{U} / \mathrm{ml}$ for aCL IgG, IgA; $7 \mathrm{U} / \mathrm{ml}$ for aCL IgM; $5 \mathrm{U} / \mathrm{ml}$ for anti- $\beta_{2}$-GPI IgG, IgM, IgA; and $25 \mathrm{U} / \mathrm{ml}$ for ACPA.

Antiendothelial cell antibodies were measured by ELISA. In brief, second-passage human umbilical vein endothelial cells were seeded at $2 \times$ $10^{4}$ in $100 \mu 1$ on sterile 96-well microtiter plates precoated with $100 \mu 11 \%$ gelatin. After $48 \mathrm{~h}$ culture, the plates were washed 3 times with phosphate-buffered saline (PBS; $0.15 \mathrm{~mol} / \mathrm{l}, \mathrm{pH}$ 7.4) then blocked with PBS containing $1 \%$ bovine serum albumin (BSA) for $2 \mathrm{~h}$ at room temperature. After 3 washes, $100 \mu 1$ of test or reference serum samples diluted 1:100 in PBS containing $1 \%$ BSA were added to each well in triplicate and incubated $1 \mathrm{~h}$ at room temperature. After 3 washes, $100 \mu 1$ peroxidase-conjugated goat anti-human $\operatorname{IgG}$ (Dako) diluted 1:6000 in PBS containing $1 \%$ BSA was added to each well for an additional $1 \mathrm{~h}$. After 3 washes, the plates were developed with $100 \mu 1$ of $4 \mathrm{mmol} / \mathrm{l}$ o-phenylene diamine dihydrochloride (Sigma) and $1.3 \mathrm{mmol} / \mathrm{l}$ hydrogen peroxide in 0.1

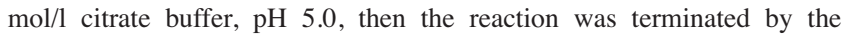
addition of $100 \mu 1$ of $2 \mathrm{~mol} / \mathrm{l}$ sulfuric acid. The optical density was measured at $492 \mathrm{~nm}$ on a microplate reader. Blank wells, calibrator, and positive and negative control sera were included on each plate. Results were calculated by 1-point calibration and expressed as arbitrary unit/ml. Cutoff of $35 \mathrm{U} / \mathrm{ml}$ was determined on a healthy control population (nonparametric method, 97.5 percentile) ${ }^{27}$.

Diagnostic studies and procedures. The first investigations were carried out at time of diagnosis of MCTD; patients were followed up every 3 months throughout the entire study. Diagnostic procedures for MCTD included radiographs, computed tomography (CT), and magnetic resonance imaging (MRI), lung function tests, electromyography, and electroneurography. Esophageal involvement was detected by radionuclide esophageal transit scintigraphy and radiographic passage using gastrographin or barium ${ }^{14}$. RP was assessed by a positive color chart or cold test and morphological abnormalities by nailfold capillary microscopy (Nikon Corp.). The capillaroscopic observations were as described: by the presence of enlarged and giant capillaries, microhemorrhages, loss of capillaries, and bushy capillaries ${ }^{28}$. The "scleroderma-like" capillaroscopic picture is characterized by the presence of giant capillaries, hemorrhages, and avascular areas $^{29}$.

High-resolution CT scan (HRCT) of the chest was performed when indicated by pulmonary function tests, including DLCO.

Open-lung biopsy was carried out in 11 cases and transbronchial biopsy in 8 cases, when the origin of the pulmonary disease was not clear by radiography or HRCT. Lung biopsy showed interstitial lung disease (ILD) in 16 cases and pulmonary arterial hypertension (PAH) in 3 cases.

Myositis was confirmed by muscle biopsy and/or electromyogram and CK elevation.

Eight patients with proteinuria underwent renal biopsy, and results were assigned to the International Society of Nephrology (ISN) Renal Pathology Society Classification World Health Organization classes ${ }^{30}$.

PAH was diagnosed by Doppler echocardiography, when the systolic pressure of the right ventricle was $\geq 25 \mathrm{~mm} \mathrm{Hg}$ at rest. Right ventricle catheterization was performed on 22 patients, with simultaneous Doppler echocardiography.

In patients with MCTD, secondary antiphospholipid syndrome (APS) was defined if at least 1 of the 2 major clinical criteria (vascular thrombosis, pregnancy morbidity) and 1 of the laboratory criteria were met $^{31,32,33}$. Laboratory criteria include aCL antibody of $\mathrm{IgG}$ and/or IgM isotype, anti- $\beta_{2}$-GPI antibody $\operatorname{IgG}$ and/or IgM isotype, or lupus anticoagulant present in plasma on 2 or more occasions at least 12 weeks apart.

Clinical disease activity was assessed retrospectively by the Systemic Lupus Activity Measure (SLAM) from the patients' reports ${ }^{7}$. A SLAM value $>6$ was considered high disease activity.

Statistical analysis. Data were analyzed using SPSS for Windows 20.0 software. Differences in frequencies of systemic manifestations among the living and deceased patients and correlations among the supposed prognostic factors were examined by chi-square test. Univariate analysis of survival was performed with the Kaplan-Meier method. The log-rank test was used to determine the statistical significance of the observed differences in the survival rates between those with different organ involvement. $P$ values $\leq 0.05$ were considered significant.

\section{RESULTS}

Clinical features. The main clinical manifestations and laboratory features of the 280 patients at time of diagnosis of MCTD and the cumulative findings are summarized in Table 1. The patients had a mean SLAM score of $13.1 \pm 1.4$ (range 3-26) at time of the last investigation. 
Table 1. The frequencies of systemic involvement and autoantibody positivity at time of diagnosis of mixed connective tissue disease (MCTD) and cumulative frequencies during the disease course.

\begin{tabular}{|c|c|c|c|}
\hline Clinical Features & $\begin{array}{l}\text { At Time of Diagnosis } \\
\text { of MCTD, } n=280\end{array}$ & $\begin{array}{c}\text { Cumulative Frequency } \\
\text { During the Disease Course } \\
\qquad \mathrm{n}=280\end{array}$ & , \\
\hline Polyarthritis (erosive and non-erosive) & $183(65.3)$ & $251(89.6)$ & $<0.0001$ \\
\hline Puffy edema of dorsal hand & $150(53.6)$ & $156(55.7)$ & 0.1 \\
\hline Pulmonary arterial hypertension & 0 & $50(17.8)$ & - \\
\hline Raynaud phenomenon & $141(50.3)$ & $161(57.5)$ & 0.10 \\
\hline Myositis & $38(13.5)$ & $91(32.5)$ & 0.0001 \\
\hline Sclerodactyly & $99(35.3)$ & $117(41.8)$ & 0.1399 \\
\hline Interstitial lung disease & $2(0.7)$ & $132(47.1)$ & 0.0001 \\
\hline Pleuritis/pericarditis & 39 (13.9) & $83(29.6)$ & 0.001 \\
\hline Nervous system disease & $35(12.5)$ & $56(20.0)$ & 0.02 \\
\hline Skin involvement* & $92(32.9)$ & $102(36.4)$ & 0.06 \\
\hline Renal disease & 0 & $11(3.9)$ & - \\
\hline Esophageal dysmotility & $109(38.9)$ & $139(49.6)$ & 0.01 \\
\hline Cancer & 0 & $16(5.7)$ & - \\
\hline Cardiovascular involvement & $21(7.5)$ & $98(35.0)$ & $<0.0001$ \\
\hline Antiphospholipid syndrome & $11(3.9)$ & $72(25.7)$ & $<0.0001$ \\
\hline \multicolumn{4}{|c|}{ Laboratory and immunoserological abnormalities } \\
\hline Anemia & $52(18.5)$ & $63(22.5)$ & 0.295 \\
\hline Thrombocytopenia & $19(6.7)$ & $29(10.3)$ & 0.173 \\
\hline Antiendothelial cell antibody positivity & $48(17.1)$ & $94(33.5)$ & $<0.0001$ \\
\hline Anticardiolipin antibody positivity & $53(18.9)$ & $98(35.0)$ & $<0.0001$ \\
\hline Anti- $\beta_{2}$-GPI antibody positivity & $42(15.0)$ & $79(28.2)$ & $<0.0001$ \\
\hline Anti-SSA positivity & $92(32.8)$ & $94(33.5)$ & 0.42 \\
\hline Anti-dsDNA positivity & $2(0.7)$ & $9(3.2)$ & 0.06 \\
\hline Anti-Sm positivity & $10(3.5)$ & $19(6.7)$ & 0.125 \\
\hline ACPA positivity & $21 / 178 * *(11.7)$ & $53(18.9)$ & 0.05 \\
\hline
\end{tabular}

During the followup period the frequency of esophageal hypomotility and nervous system disease increased, and new symptoms developed, such as PAH, ILD, thrombotic events, and renal disease.

The most frequent symptoms in our series were polyarthritis $(89.6 \%), \operatorname{RP}(57.5 \%), \operatorname{ILD}(47.1 \%)$, esophageal dysmotility $(49.6 \%)$, and sclerodactyly $(41.8 \%)$. Arthritis appeared to be the most common symptom in our patients. Arthritis was located mainly in the interphalangeal and metacarpophalangeal joints of the hands and feet. Arthritis was symmetric and nondeforming in 207/251 patients (82.5\%). Erosive arthritis was diagnosed in $44(17.5 \%)$ patients during the disease course, and interestingly, erosions developed 5 to 10 years after the onset of MCTD.

RP was detected in $57.5 \%$ of patients. Nailfold capillaroscopy showed significant and gradual progression of the vascular abnormalities during the followup period of patients with MCTD. The typical form of the "scleroderma pattern" was at the time of diagnosis of MCTD in $31.4 \%$ of patients, and during the mean 13.1 years' followup period there was a weak progression $(40.3 \% ; \mathrm{p}<0.03)$. Out of the 258 living patients, $38.3 \%$ had scleroderma pattern, while 14 of the $22(63.3 \%)$ deceased patients had scleroderma pattern $(\mathrm{p}<0.02)$. However, we found no difference in the presence of scleroderma pattern between MCTD patients with PAH and patients without PAH.

One hundred thirty-two patients had ILD. ILD was recurrent in 24 cases. Pulmonary biopsy was undertaken in 16 cases, when we could not exclude tumor, sarcoidosis, or lymphoma. The histological investigation in all 16 patients showed nonspecific interstitial pneumonitis (NSIP) with mononuclear cell infiltration in the lung parenchyma. In 11 patients the histological picture showed cellular interstitial pneumonitis with little or no fibrosis, while in 5 patients significant fibrosis developed. Immunohistochemical analysis in all cases revealed epithelial deposits of $\mathrm{C} 3$ complement and immunoglobulin M. Interestingly, no sera samples from patients with ILD were positive for anti-Jo1 antibody.

PAH developed in 50 patients $14.5 \pm 3.71$ years after the diagnosis of MCTD. Initially, the symptoms of PAH were very mild and nonspecific, and it was difficult to identify $\mathrm{PAH}$ at this stage. As the disease progressed, nonspecific symptoms such as shortness of breath or fatigue developed. Subsequently, the symptoms quickly progressed to choking, fever, hemoptysis, and tachypnea. In our series the 
pulmonary arterial pressure was between 40 and $60 \mathrm{~mm} \mathrm{Hg}$ by echocardiography, confirmed by right heart pulmonary arterial catheterization. All patients with $\mathrm{PAH}$ had continuously high levels of anti-U1-RNP (> $30 \mathrm{U} / \mathrm{ml})$, while $42 / 50$ $(84.0 \%)$ patients were positive for antiendothelial cell antibodies (AECA). These findings suggested that high levels of anti-U1-RNP can contribute to endothelial cell proliferation.

In our series renal involvement was observed in only $3.9 \%$. Three patients had thrombotic thrombocytopenic purpura or hemolytic uremic syndrome (TTP/HUS)-associated nephropathy. Eight patients had glomerulonephritis (GN). Every 8 patients with proteinuria underwent renal biopsy, and the biopsies showed ISN class II mesangial proliferative GN in 5 patients and focal nephritis in 3 patients.

Cardiovascular disease such as cardiomyopathy, valvular changes, arrhythmia, and ischemic heart disease was found in 98 patients. Pacemaker therapy was needed for 5 patients.

We observed that MCTD may be associated with secondary APS. Seventy-two patients had thrombotic events with antiphospholipid antibody positivity, and these patients fulfilled the classification criteria for APS ${ }^{33}$. Fifty-nine of 72 patients $(81.9 \%)$ had venous thromboses, 9 patients suffered cerebral vascular attacks $(12.5 \%)$, and $4(5.5 \%)$ had arterial occlusion in the lower extremities.

Malignancy developed in 16 patients with MCTD during the disease course: gastrointestinal cancer was the most common $(n=8)$, followed by breast $(n=2)$, cervix $(n=2)$, bronchial $(\mathrm{n}=2)$, and pancreatic and esophageal cancer (1-1 for each type). Among those 258 patients who survived, 10 had tumor (3.8\%), while among the 22 who died, 6 patients $(27.2 \%)$ had had cancer; however, the cause of death was not the tumor itself.

Autoantibodies in patients with MCTD. ANA and anti-U1-RNP autoantibodies were detected in all patients' sera samples. However, patients' sera were positive for other autoantibodies, such as AECA (33.5\%); aCL IgG, IgA, and IgM (35.0\%; IgG $\mathrm{n}=58, \operatorname{Ig} \mathrm{A} \mathrm{n}=21, \operatorname{IgM} \mathrm{n}=19$ patients); anti- $\beta_{2}$-GPI $(28.2 \%$; $\operatorname{IgG} n=40, \operatorname{IgA} n=22, \operatorname{IgM} n=17$ patients); ACPA (18.9\%); and anti-SSA (32.8\%); and anti-dsDNA $(3.2 \%)$ and anti-Sm $(6.7 \%)$ were also present.

We found a close association between cardiovascular events and the presence of aCL IgG, IgM, and IgA autoantibodies (IgG/IgM: RR 2.925, 95\% CI 1.50-5.7; IgA: RR $3.059,95 \%$ CI $1.15-8.1)$. We found that anti- $\beta_{2}$-GPI IgG, $\operatorname{IgM}$, and $\operatorname{IgA}$ antibodies were more frequent in patients with cardiovascular diseases and were associated with cardiovascular disease severity (anti- $\beta_{2}$-GPI IgG/IgM: RR $2.79,95 \%$ CI 1.41-5.5; anti- $\beta_{2}$-GPI IgA: RR 6.2, 95\% CI 2.2-17.7). We found association between arterial/venous thrombotic events and AECA (RR 2.917, 95\% CI 1.58-5.36) and aCL IgG antibodies (RR 31.39, 95\% CI 1.76-54.26); however, there was no significant association between thrombosis and
aCL IgM (RR 0.08, 95\% CI 0.003-2.1). Anti- $\beta_{2}$-GPI IgG and IgM showed strong association with thrombotic processes (anti- $\beta_{2}$-GPI IgG: RR 22.4, 95\% CI 1.20-417.9; anti- $\beta_{2}$-GPI IgM: RR 23.3, 95\% CI 1.06-512.0). Patients with PAH showed association with AECA (RR 56.43, 95\% CI 19.8-160.8) and aCL IgG/A/M (RR 3.67, 95\% CI 1.61-8.3); however, there was no association with anti- $\beta_{2}$-GPI IgG, IgA, and IgM (RR 0.35, 95\% CI 0.10-1.1). Causes of death. During the observational period, 22 of 280 patients died; causes of death are given in Table 2. PAH was the major complication of MCTD. During the followup period, in spite of adequate therapy, 9 patients died $0.5-2$ years after the diagnosis of PAH. These patients' conditions worsened rapidly, and they developed hemoptysis, tachypnea, and finally cardiac arrest. Development of PAH in these patients was rapid, and Doppler echocardiography showed $>60 \mathrm{~mm} \mathrm{Hg}$ systolic pulmonary arterial pressure, confirmed by right heart catheterization. Vasculopathy of pulmonary artery vessels was detected in 3 patients under open lung biopsy, and in 2 patients at autopsy.

Three patients died with TTP/HUS. The occurrence of TTP in MCTD is rare. In one patient, fresh CMV infection provoked TTP. The patients with TTP did not respond to steroid pulse therapy, plasma exchange, or fresh-frozen plasma, and finally died 4-8 days after the onset of neuropsychiatric symptoms. These patients suffered from endstage renal failure and the prognosis was extremely poor.

Three patients with MCTD died from infections. Two patients had hepatitis C virus (HCV) infection, which provoked hepatic coma after 12 and 15 years of diagnosis of MCTD, respectively. One patient received subcutaneous injection of pegylated interferon- $\alpha-2 \mathrm{a} 180 \mu \mathrm{g}$ weekly and oral ribavirin $1000 \mathrm{mg} /$ day. Serum HCV RNA levels were evaluated quantitatively by RT-PCR analysis (Cobas TaqMan HCV Test, Roche Diagnostics; cutoff value 25 $\mathrm{IU} / \mathrm{ml}) 48$ weeks after treatment. Biopsy was performed after treatment: the histology activity index was 18 , and the fibrosis score was 6 , with signs of cirrhosis. The other patient with hepatitis infection did not receive antiviral therapy because he had anemia $(8 \mathrm{~g} / \mathrm{dl})$ and neutropenia

Table 2. Causes of death in 22 patients with mixed connective tissue disease (MCTD).

\begin{tabular}{lcc}
\hline Cause of Death & No. Patients $(\%)$ & $\begin{array}{c}\text { Duration of MCTD at } \\
\text { Time of Death, yrs }\end{array}$ \\
\hline Disease manifestations & $12(54.5)$ & \\
PAH & $9(40.9)$ & $17,9,15,14,16,8,17,16,19$ \\
TTP/HUS & $3(13.6)$ & $3,13,1$ \\
Disease complications & $10(45.4)$ & $8,12,15$ \\
Infections & $3(13.6)$ & $10,4,6,15,3,12,26$ \\
Acute cardiovascular events & $7(31.8)$ & \\
\hline
\end{tabular}

PAH: pulmonary arterial hypertension; TTP/HUS: thrombotic thrombocytopenic purpura or hemolytic uremic syndrome.

Personal non-commercial use only. The Journal of Rheumatology Copyright $\odot$ 2013. All rights reserved. 
(neutrophil count $<1500$ cells $/ \mu 1$ ), and the cirrhosis was decompensated (Child-Pugh class B). One patient died of staphylococcal sepsis.

Cardiovascular events in MCTD were associated with a relatively poor prognosis. Among patients who died, 2 had dilatative cardiomyopathy (DCM) and congestive heart failure caused the death, accompanied by ventricular arrhythmias. The underlying pathophysiologic mechanisms that caused DCM could have been myocarditis, coronary artery disease, and small vessel vasculopathy of the myocardium. In one patient the autopsy showed severe myocarditis. Five patients had severe coronary sclerosis with ischemic cardiomyopathy and arrhythmias, and 2 died of acute myocardial infarction.

Influence of clinical features on survival. Figure 1 represents the survival curve in our series: 5, 10, and 15-year survival rates were $98 \%, 96 \%$, and $88 \%$, respectively, for patients with MCTD. Cardiovascular events significantly worsened the survival outlook ( $<<0.001$; Figure 2A). MCTD patients with PAH had significantly worse cumulative survival probability than patients without $\mathrm{PAH}$ $(\mathrm{p}=0.021$; Figure 2B). There was no difference in the survival probability in patients with and those without ILD and myositis (Figure 2C-2D).

We used univariate analysis to compare the clinical measures and the presence of autoantibodies between the living and deceased patients (Table 3). The patients who died were younger at the time of the diagnosis of MCTD, compared to those who survived (patients who died $35.5 \pm$ 10.4 yrs vs living patients $41.8 \pm 10.7 \mathrm{yrs} ; \mathrm{p}=0.03$ ), while there was no difference between the followup periods (patients who died $13.2 \pm 7.6$ yrs vs living patients $12.3 \pm$ 7.5 yrs; $p=0.835$ ). Our cohort study showed that the presence of cardiovascular events $(\mathrm{p}<0.001$, RR 3.625, 95\% CI 0.463-8.979), PAH ( $\mathrm{p}=0.0071, \mathrm{RR} 3.664,95 \%$ CI

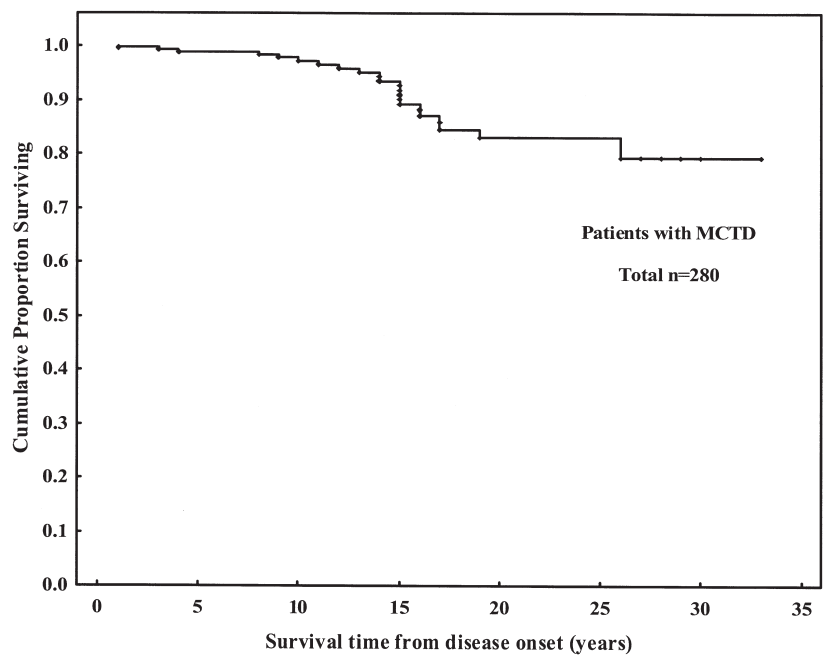

Figure 1. Overall survival of patients with mixed connective tissue disease (MCTD).
1.47-9.133), serositis ( $\mathrm{p}<0.001, \mathrm{RR} 4.79,95 \%$ CI $1.926-11.927)$, and secondary APS ( $p=0.039$, RR 2.63, 95\% CI 1.085-6.394) increased the risk of the mortality. Esophageal hypomotility $(\mathrm{p}=0.04, \mathrm{RR} 2.837,95 \%$ CI 1.076-7.483), kidney involvement ( $\mathrm{p}=0.04, \mathrm{RR} 4.93,95 \%$ CI 1.208-20.147), and malignant tumors ( $\mathrm{p}<0.001$, RR 9.3, 95\% CI 2.99-28.837) also limited the MCTD patients' survival.

The presence of aCL $(\mathrm{p}=0.019, \mathrm{RR} 2.94,95 \%$ CI $1.209-7.151)$, anti- $\beta_{2}$-GPI $(\mathrm{p}=0.002$, RR $4.202,95 \%$ CI 1.717-10.283), and AECA ( $\mathrm{p}=0.002$, RR $6.154,95 \%$ CI $2.30-16.321$ ) increased the risk of mortality.

The high-dose corticosteroid or immunosuppressive therapy did not influence the patients' survival.

Therapeutic considerations. In our study all patients received corticosteroid (CS) treatment. Basic immunosuppressive therapy is shown in Table 4. Skin manifestations were treated with CS and/or antimalarials. Flares of arthritis were treated with low-dose CS, antimalarials, or methotrexate (MTX). Forty-four patients with erosive arthritis received MTX 15-20 mg/week, alone or in combination with tumor necrosis factor- $\alpha$ (TNF- $\alpha$ ) blockers. MTX was the most effective therapy in patients with active arthritis and bone erosions. Serositis showed good response to CS. Pulmonary involvement required complex therapy. Patients with ILD received high-dose CS, often pulse CS combined with cyclophosphamide (CYC) or mycophenolate mofetil. PAH was treated with high-dose CS or pulse CS and CYC, and often prostanoids, endothelin receptor 2 antagonists, phosphodiesterase-5 inhibitors, and anticoagulants were also added to the therapy. In cases of renal involvement, CS and CYC were given to the patients. Myositis was treated with CS, in severe cases CYC and IVIG therapy were added to $\mathrm{CS}$.

The cumulative percentages of patients who received CYC, MTX, and azathioprine were $66.4 \%, 16.4 \%$, and $2.1 \%$, respectively.

\section{DISCUSSION}

We have summarized findings of a prospective study on the survival and prognostic indicators of MCTD in a Hungarian population. Our work was performed on a cohort of 280 patients followed between 1979 and 2011. All patients fulfilled the diagnostic criteria established by Alarcon-Segovia and Villarreal ${ }^{26}$ for MCTD. The patients with MCTD in our cohort were characterized by female predominance (8:1), similar to previous studies ${ }^{4,15,16}$. During the followup period new symptoms developed; however, the patients did not show progression to other systemic autoimmune diseases, such as systemic sclerosis or systemic lupus erythematosus (SLE).

The overall 5-year and 10-year survival rates of our patients with MCTD were $98 \%$ and $96 \%$, respectively, and these results were better than those earlier reported by

Personal non-commercial use only. The Journal of Rheumatology Copyright (c 2013. All rights reserved. 
A

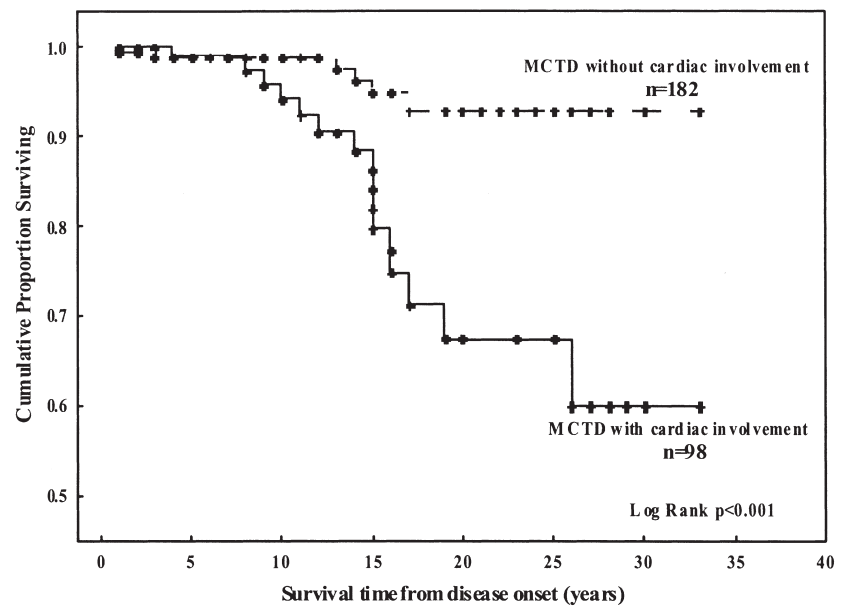

C

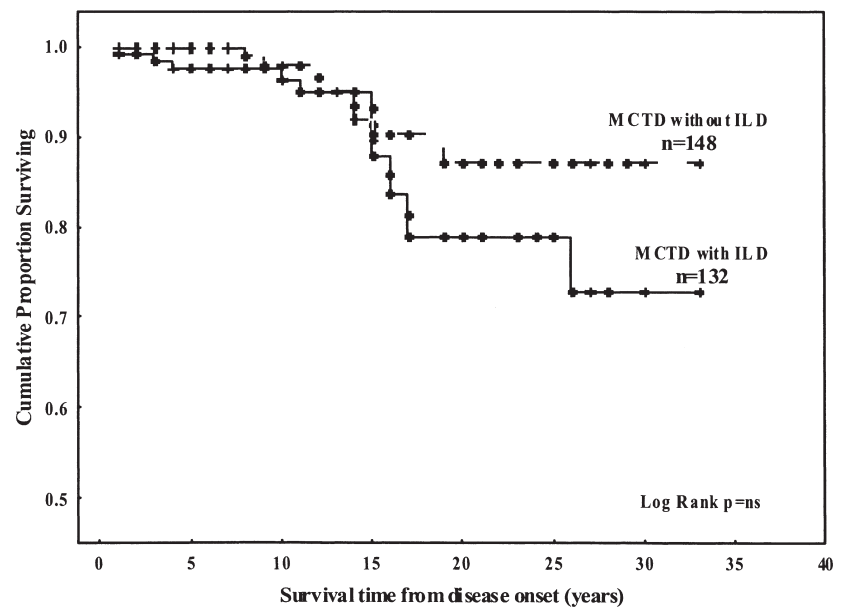

B

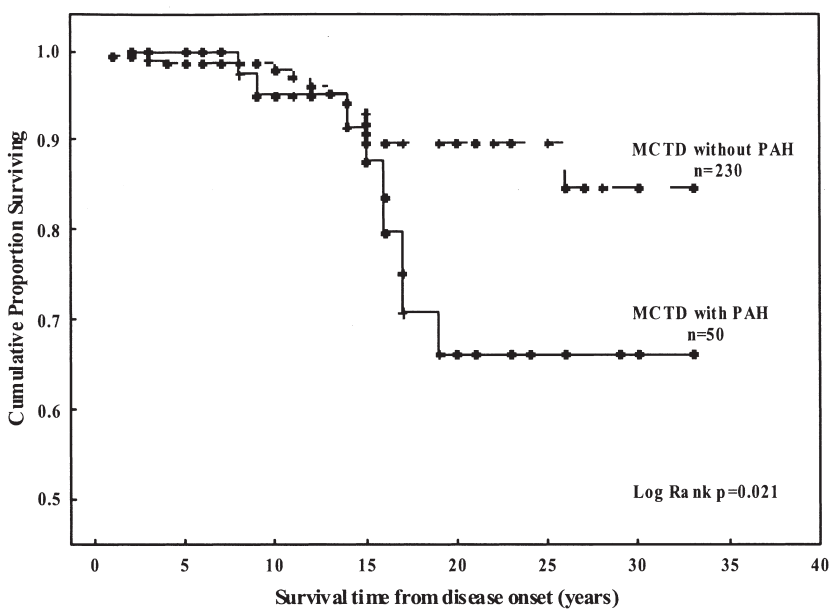

D

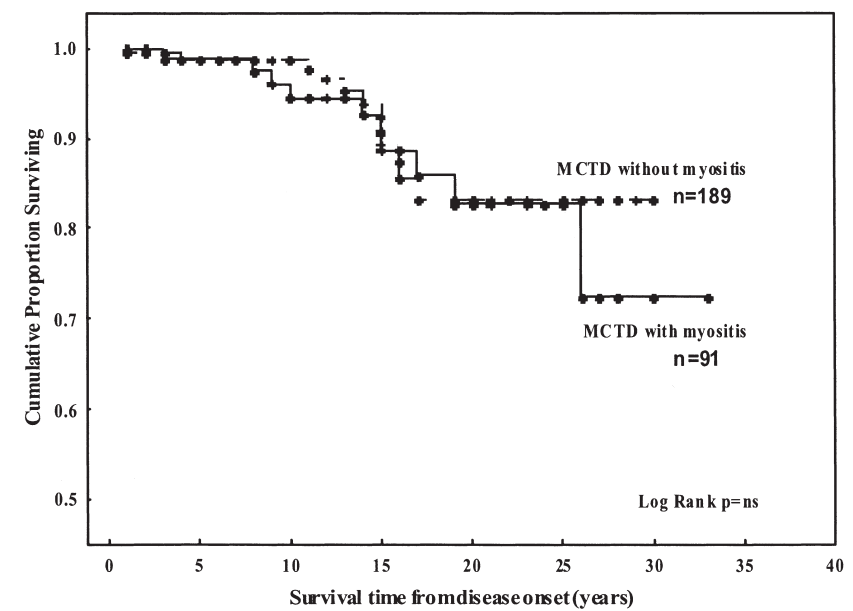

Figure 2. Survival of patients with mixed connective tissue disease (MCTD) within various disease subgroups. A. Survival of patients with and without cardiovascular disease. B. Survival of patients with and without pulmonary arterial hypertension (PAH). C. Survival of patients with and without interstitial lung disease (ILD). D. Survival of patients with and without myositis.

Miyawaki and Onodera ${ }^{17}$. In our study 22 patients died (7.8\%) among 280 patients. In 12 patients the cause of death was the manifestations of the MCTD itself (in 9 patients $\mathrm{PAH}$; in 3 patients TTP/HUS), in 10 patients the cause of death was related to complications of MCTD (cardiovascular events and infections).

Our data showed that accelerated atherosclerosis occurs in patients with MCTD. Earlier we reported in patients with MCTD that total cholesterol, the traditional risk factor for atherosclerosis, was increased, and paraoxonase activity and ApoA1 levels decreased ${ }^{34}$. High-sensitivity C-reactive protein levels were found to be elevated in MCTD, reflecting vascular inflammation in these patients. Endothelial dysfunction, characterized by decreased flow-mediated vasodilation, and nitrate-mediated vasodilation are very early signs in the development of atherosclerosis $^{35,36}$. We also observed previously that vitamin D deficiency increased the cardiovascular morbidity in
MCTD $^{37}$. Elevated levels of AECA, aCL, and anti- $\beta_{2}$-GPI autoantibodies are important atherogenic factors in patients with $\mathrm{MCTD}^{38}$.

PAH remained the major cause of death in MCTD. The prevalence of MCTD-associated PAH is between $8.8 \%$ and $23.4 \%{ }^{39,40}$. The survival of patients with MCTD-PAH under current treatment is better compared to results from older studies $^{17,41,42,43}$. In addition to CS and immunosuppressive drugs, other advanced therapies such as prostanoids, endothelin receptor antagonists, and phosphodiesterase-5 inhibitors have been shown to improve pulmonary functional status in MCTD patients with PAH.

The exact pathological mechanism of PAH in MCTD remains unknown. Hasegawa, et al found that the anti- $\beta_{2}$-GPI IgG level was higher among MCTD patients with PAH compared to those without $\mathrm{PAH}^{44}$. We and others determined that the serum concentrations of anti-U1-RNP, aCL antibodies, and AECA were higher in the MCTD-PAH cases

Personal non-commercial use only. The Journal of Rheumatology Copyright @ 
Table 3. Effects of clinical and serological characteristics on survival during the disease course of mixed connective tissue disease (MCTD).

\begin{tabular}{|c|c|c|c|c|c|}
\hline Characteristics & $\begin{array}{l}\text { Living Patients, } \\
\quad \mathrm{n}=258\end{array}$ & $\begin{array}{c}\text { Deceased Patients, } \\
\mathrm{n}=22\end{array}$ & $\mathrm{p}$ & $95 \% \mathrm{CI}$ & $\mathrm{RR}$ \\
\hline Age at diagnosis of MCTD, yrs & $41.8 \pm 10.7$ & $35.5 \pm 10.4$ & 0.03 & & \\
\hline Disease duration, yrs & $\begin{array}{l}13.2 \pm 7.6 \\
(\mathrm{r}: 1-29)\end{array}$ & $\begin{array}{l}12.3 \pm 7.5 \\
(\mathrm{r}: 1-26)\end{array}$ & 0.835 & & \\
\hline Polyarthritis & 192 & 15 & 0.612 & $0.2878-1.886$ & 0.736 \\
\hline Raynaud phenomenon & 151 & 10 & 0.265 & $0.2461-1.417$ & 0.5905 \\
\hline Pulmonary arterial hypertension & 41 & 9 & 0.0071 & $1.47-9.133$ & 3.664 \\
\hline Myositis & 81 & 10 & 0.234 & $0.7556-4.389$ & 1.821 \\
\hline Interstitial lung disease & 124 & 8 & 0.3750 & $0.2504-1.523$ & 0.6175 \\
\hline Serositis & 69 & 14 & $<0.001$ & $1.926-11.927$ & 4.793 \\
\hline Esophageal hypomotility & 133 & 6 & 0.04 & $1.076-7.483$ & 2.837 \\
\hline CNS involvement & 52 & 4 & 1.0 & $0.2856-2.713$ & 0.8803 \\
\hline Sclerodactyly & 102 & 15 & 0.8226 & $0.3544-2.040$ & 0.8503 \\
\hline Skin manifestations & 95 & 7 & 0.8181 & $0.3152-2.034$ & 0.800 \\
\hline Kidney involvement & 8 & $3 *$ & 0.04 & $1.208-20.147$ & 4.934 \\
\hline Cardiovascular events & 84 & 14 & $<0.0001$ & $1.463-8.979$ & 3.625 \\
\hline Cancer & 10 & 6 & $<0.001$ & $2.999-28.837$ & 9.3 \\
\hline Antiphospholipid syndrome & 62 & 10 & 0.039 & $1.085-6.394$ & 2.634 \\
\hline AECA positivity & 78 & 16 & 0.002 & $2.30-16.321$ & 6.154 \\
\hline aCL $\mathrm{IgG} / \mathrm{M} / \mathrm{A}$ positivity & 85 & 13 & 0.0190 & $1.209-7.151$ & 2.94 \\
\hline Anti- $\beta_{2}$-GPI IgG/M/A positivity & 66 & 13 & 0.002 & $1.717-10.283$ & 4.202 \\
\hline Anti-SSA positivity & 88 & 4 & 0.1587 & $0.1409-1.308$ & 0.4293 \\
\hline Anti-dsDNA positivity & 9 & 0 & - & - & - \\
\hline Anti-Sm positivity & 17 & 2 & 0.6516 & $0.1520-3.274$ & 0.705 \\
\hline ACPA positivity & 51 & 2 & 0.2710 & $0.0918-1.793$ & 0.4059 \\
\hline Treatment with high-dose steroid ${ }^{\dagger}$ & 201 & 18 & 0.783 & $0.2549-2.409$ & 0.783 \\
\hline Treatment with cytotoxic agent ${ }^{\dagger \dagger}$ & 190 & 19 & 0.305 & $0.1265-1.538$ & 0.4412 \\
\hline $\begin{array}{l}\text { Treatment with anti-TNF- } \alpha \\
\text { monoclonal antibodies }\end{array}$ & 42 & 0 & - & - & - \\
\hline
\end{tabular}

$*$ Kidney damage due to thrombotic thrombocytopenic purpura. ${ }^{\dagger}$ Dosage $\geq 1 \mathrm{mg} / \mathrm{kg} / \mathrm{day}$ methylprednisolone.

${ }^{\dagger}$ Methotrexate, cyclophosphamide, or azathioprine. CNS: central nervous system; AECA: antiendothelial cell antibody; aCL: anticardiolipin antibody; anti- $\beta_{2}$-GPI: $\beta_{2}$-glycoprotein I antibody; ACPA: anticitrullinated protein antibody; TNF- $\alpha$ tumor necrosis factor- $\alpha$.

Table 4. Basic immunosuppressive therapy in 280 patients with mixed connective tissue disease (MCTD).

\begin{tabular}{ll}
\hline Clinical Symptoms (no. patients) & Treatment \\
\hline Skin (rash, photosensitivity; $\mathrm{n}=102)$ & CS and antimalarials \\
Arthritis $(\mathrm{n}=207)$ & Antimalarials, low-dose CS (prednisone $\leq 20 \mathrm{mg} /$ day), MTX for flares \\
Erosive arthritis $(\mathrm{n}=44)$ & MTX, disease-modifying agents such as TNF- $\alpha$ blockers \\
Serositis $(\mathrm{n}=83)$ & $0.25-1 \mathrm{mg} / \mathrm{kg} \mathrm{CS}$ \\
Pulmonary involvement & \\
Interstitial lung disease $(\mathrm{n}=132)$ & High-dose CS* $(\geq 1 \mathrm{mg} / \mathrm{kg})$, often pulse CS $(1 \mathrm{~g} / \mathrm{day}$ for 3 days), and CYC or MMF \\
Pulmonary arterial hypertension $(\mathrm{n}=50)$ & High-dose CS* $(\geq 1 \mathrm{mg} / \mathrm{kg})$, often pulse CS $(1 \mathrm{~g} / \mathrm{day}$ for 3 days), CYC \\
& In addition: prostanoids, endothelin receptor antagonists, phosphodiesterase-5 inhibitor, \\
& and anticoagulants $(\mathrm{LMWH})$ \\
Renal disease $(\mathrm{n}=8)$ & $\mathrm{CS}(0.25-1.0 \mathrm{mg} / \mathrm{day}), \mathrm{CYC}$ \\
Myositis $(\mathrm{n}=91)$ & $\mathrm{CS}(0.5-1 \mathrm{mg} / \mathrm{kg})$ \\
& Consider CYC or IVIG, azathioprine
\end{tabular}

\footnotetext{
* Dosage $\geq 1 \mathrm{mg} / \mathrm{kg} /$ day methylprednisolone. MTX: methotrexate; CYC: cyclophosphamide; MMF: mycophenolate mofetil; IVIG: intravenous immune globulin; CS: corticosteroid; LMWH: low molecular weight heparin; TNF: tumor necrosis factor.
}

than in the MCTD cases without PAH ${ }^{38,45}$. Although there are growing numbers of reports of successful treatment of MCTD-PAH, PAH is still considered a severe complication of MCTD, seriously worsening the prognosis of the disease ${ }^{46,47,48}$. AECA in the sera of patients with MCTD can activate endothelial cells and provoke surface adhesive 
proteins. AECA are often associated with aCL antibody reactivity ${ }^{27}$. Others did not find association between AECA and $\mathrm{aCL}$ antibodies in SLE-PAH patients ${ }^{49}$.

TTP is a rare and occasionally fatal hematologic disorder in MCTD $^{50,51}$. Three patients developed TTP/HUS, and all died. These patients had active disease with severe arthritis and pericardial fluid. The progression of symptoms was extremely fast, and they were refractory to any treatment modalities, including plasmapheresis. Platelet and fibrin thrombi occluded capillaries and arterioles in the kidney, pancreas, myocardium, brain, and other organs.

In our series, infections also played a pivotal role in the mortality. HCV infection worsened the condition of 2 patients. Permanent CS treatment was necessary in these 2 patients, because they had recurrent ILD. The third patient died in staphylococcus sepsis, after the active myositis had been treated with CS.

Many autoimmune diseases have been reported to be associated with malignancies. In MCTD there are only case reports about coexisting malignant tumors ${ }^{52,53}$. In our series, 16 out of 280 patients $(5.7 \%)$ had malignant neoplasms. Six patients died; however, the cause of death was not the tumor itself. The prevalence of malignancies in our MCTD group was similar to those reported for Hungarian SLE (4.3\%) and systemic sclerosis populations $(4.6 \%)^{54,55}$.

Immunosuppressive therapy is a key factor affecting survival in systemic autoimmune diseases. Immunosuppression decreases the organ damage, but immunosuppressive treatment may also increase longterm morbidity associated with adverse effects, such as increasing the risk of infections and tumors. In our series there was no significant difference in the treatment with high-dose steroids and cytotoxic agents between the living and deceased patients.

We conclude that MCTD is a distinct entity, with well-defined clinical symptoms. The probability of survival of patients is better than 20 years ago. Despite the modern treatment, PAH remained the leading cause of death in MCTD. The traditional risk factors, the presence of autoantibodies, and vitamin D deficiency may explain the increased prevalence of atherosclerosis. Concerning aggressive therapeutic regimes in MCTD, they decrease organ damage, yet may cause novel complications such as infections, accelerated atherosclerosis, or cancer. During the last decade the number of cardiovascular events increased in MCTD. Pathological inflammatory mechanisms are clearly present in MCTD that can lead to impaired endothelial function.

We believe that monitoring accelerated atherosclerosis and cardiovascular risk factors is an important diagnostic and followup task in modern management of patients with MCTD.

\section{REFERENCES}

1. Sharp GC, Irvin WS, Tan EM, Gould RG, Holman HR. Mixed connective tissue disease - An apparently distinct rheumatic disease syndrome associated with a specific antibody to an extractable nuclear antigen (ENA). Am J Med 1972;52:148-59.

2. Sharp GC, Irvin WS, LaRoque RL, Velez C, Daly V, Kaiser AD, et al. Association of autoantibodies to different nuclear antigens with clinical patterns of rheumatic disease and responsiveness to therapy. J Clin Invest 1971;50:350-9.

3. Hoffmann RW, Cassidy JT, Takeda Y, Smith-Jones EL, Wang GS, Sharp GC. U1-70 kD autoantibody positive connective tissue disease in children: A longitudinal clinical and serological analysis. Arthritis Rheum 1993;36:1599-602.

4. Kasukawa R. Mixed connective tissue disease. Intern Med 1999;38:386-93.

5. O'Connell DJ, Bennett RM. Mixed connective tissue disease: Clinical and radiological aspects of 20 cases. Br J Radiol 1970;50:620-5.

6. Takasaki Y, Yamanaka K, Takasaki C, Matsushita M, Yamada H, Nawata M, et al. Anticyclic citrullinated peptide antibodies in patients in mixed connective tissue disease. Mod Rheumatol 2004; 14:367-75.

7. Maldonado ME, Perez M, Pignac-Kobinger J, Marx ET, Tozman EM, Greidinger EL, et al. Clinical and immunologic manifestations of mixed connective tissue disease in a Miami population compared to a Midwestern US Caucasian population. J Rheumatol 2008;35:1-9.

8. Prakash UB, Luthra HS, Divertie MB. Intrathoracic manifestations in mixed connective tissue disease. Mayo Clin Proc 1985;60:813-21.

9. Prakash UB. Lungs in mixed connective tissue disease. J Thorac Imaging 1992;7:55-61.

10. Hoffman RW, Maldonado ME. Immune pathogenesis of mixed connective tissue disease: A short analytical review. Clin Immunol 2008;128:8-17.

11. Vianna MA, Borges CT, Borba EF, Caleiro MT, Bonfá E, Marie SK. Myositis in mixed connective tissue disease: a unique syndrome characterized by immunohistopathologic elements of both polymyositis and dermatomyositis. Arq Neuropsiquiatr 2004;62:923-34.

12. Bodolay E, Szekanecz Z, Dévényi K, Galuska L, Csipő I, Végh J, et al. Evaluation of interstitial lung disease in mixed connective tissue disease (MCTD). Rheumatology 2005;44:656-61.

13. Ortega-Hernandez OD, Shoenfeld Y. Mixed connective tissue disease: An overview of clinical manifestations, diagnosis and treatment. Best Pract Res Clin Rheumatol 2012;26:61-72.

14. Gaál J, Varga J, Szabados L, Garai I, Galuska L, Surányi P, et al. High prevalence of oesophageal involvement in patients with undifferentiated connective tissue disease using radionuclide oesophageal transit scintigraphy. Nucl Med Commun 2005;26:1113-7.

15. Gunnarsson R, Molberg O, Gilboe I, Gran JT. The prevalence and incidence of mixed connective tissue disease: A national multicentre survey of Norwegian patients. PAHNOR1 Study Group. Ann Rheum Dis 2011;70:1047-51.

16. Szodoray P, Hajas A, Kardos L, Dezső B, Soos G, Zold E, et al. Distinct phenotypes in mixed connective tissue disease: Subgroups and survival. Lupus 2012;21:1412-22.

17. Miyawaki S, Onodera H. Clinical course and prognosis of patients with mixed connective tissue disease. In: Kasukawa R, Sharp GC, editors. Mixed connective tissue disease and anti-nuclear antibodies. Amsterdam: Elsevier Science Publishers B.V. (Biomedical Division); 1987:331-6.

18. Suzuki M, Hamada M, Sekiya M, Shigematsu Y, Go S, Hiwada K. Fatal pulmonary hypertension in a patient with mixed connective tissue disease: Report of an autopsy case. Intern Med 1992;31:74-7.

Personal non-commercial use only. The Journal of Rheumatology Copyright @ 2013 . All rights reserved. 
19. Ueda N, Mimura K, Sugiyama T, Kado T. Mixed connective tissue disease with fatal pulmonary hypertension and a review of literature. Virchows Arch (Pathol Anat) 1984;404:335-40.

20. Wiener-Kronish JP, Solinger AM, Warnock ML, Churg A, Ordonez $\mathrm{N}$, Golden JA. Severe pulmonary involvement in mixed connective tissue disease. Am Rev Respir Dis 1981;124:499-503.

21. Manthorpe R, Elling H, van der Meulen JT, Sorensen S. Two fatal cases of mixed connective tissue disease. Scand J Rheumatol 1980;9:7-10.

22. Greidinger EL. Delayed development of pulmonary arterial hypertension in mixed connective tissue disease. J Postgrad Med 2005;51:108

23. Bull TM, Fagan KA, Badesch DB. Pulmonary vascular manifestations of mixed connective tissue disease. Rheum Dis Clin N Am 2005;31:451-64.

24. Venables PJ. Mixed connective tissue disease. Lupus 2006;15:132-7.

25. Jones MB, Osterholm RK, Wilson RB, Martin FH, Commers JS, Bachmayer JD. Fatal pulmonary hypertension and resolving immune-complex glomerulonephritis in mixed connective tissue disease. Am J Med 1978;65:855-63.

26. Alarcon-Segovia D, Villarreal M. Classification and diagnostic criteria for mixed connective tissue disease. In: Kasukawa R, Sharp GC, editors. Mixed connective tissue disease and anti-nuclear antibodies. Amsterdam: Elsevier Science Publishers B.V. (Biomedical Division); 1987:33-40.

27. Bodolay E, Csipo I, Gál I, Sipka S, Gyimesi E, Szekanecz Z, et al. Anti-endothelial cell antibodies in mixed connective tissue disease: frequency and association with clinical symptoms. Clin Exp Rheumatol 2004;22:409-15.

28. Cutolo M, Pizzorni C, Secchi ME, Sulli A. Capillaroscopy. Best Pract Res Clin Rheumatol 2008;22:1093-108.

29. de Holanda Mafaldo Diógenes A, Bonfá E, Fuller R, Correia Caleiro MT. Capillaroscopy is a dynamic process in mixed connective tissue disease. Lupus 2007;16:254-8.

30. Weening JJ, D’Agati VD, Schwartz MM, Seshan SV, Alperts CE, Appel GB, et al. The classification of glomerulonephritis in systemic lupus erythematosus revisited. J Am Soc Nephrol 2004; $15: 241-50$.

31. Pierangeli SS, de Groot PG, Dlott J, Favaloro E, Harris EN, Lakos $\mathrm{G}$, et al. 'Criteria' aPL tests: Report of a task force and preconference workshop at the 13 th International Congress on Antiphospholipid Antibodies, Galveston, Texas, April 2010. Lupus 2011;20:182-90.

32. Asherson RA, Cervera R. "Primary", "secondary" and other variants of the antiphospholipid syndrome. Lupus 1994;3:29-38.

33. Miyakis S, Lockshin MD, Atsumi T, Branch DW, Brey RL, Cervera $\mathrm{R}$, et al. International consensus statement on an update of the classification criteria for definite antiphospholipid syndrome (APS). J Thromb Haemost 2006;4:295-306.

34. Bodolay E, Seres I, Szodoray P, Csipő I, Jakab Z, Végh J, et al. The evaluation of paraoxonase (PON) activity in patients with mixed connective tissue disease. J Rheumatol 2008;35:237-43.

35. Soltész P, Bereczki D, Szodoray P, Magyar TM, Der H, Csipő I, et al. Endothelial cell markers reflecting endothelial cell dysfunction in patients with mixed connective tissue disease. Arthritis Res Ther 2010;12:R78.

36. Soltész P, Kerekes G, Dér H, Szücs G, Szántó S, Kiss E, et al. Comparative assessment of vascular function in autoimmune rheumatic diseases: considerations of prevention and treatment. Autoimmun Rev 2011;10:416-25.

37. Hajas A, Sandor J, Csathy L, Csipő I, Barath S, Paragh G, et al. Vitamin D insufficiency in a large MCTD population. Autoimmun Rev 2011;6:317-24.

38. Vegh J, Szodoray P, Kappelmayer J, Csipő I, Udvardy M, Lakos G, et al. Clinical and immunoserological characteristics of mixed connective tissue disease (MCTD) associated with pulmonary arterial hypertension (PAH). Scand J Immunol 2006;64:69-76.

39. Burdt MA, Hoffman RW, Deutscher SL, Wang GS, Johnson JC, Sharp GC. Long-term outcome in mixed connective tissue disease: longitudinal clinical and serologic findings. Arthritis Rheum 1999;42:899-909.

40. Sullivan WD, Hurst DJ, Harmon CE, Esther JH, Agia GA, Maltby JD, et al. A prospective evaluation emphasizing pulmonary involvement in patients with mixed connective tissue disease. Medicine 1984;63:92-107.

41. Bodolay E, Gaál J, Végh J, Soltész P, Szodoray P, Lakos G, et al. Evaluation of survival in mixed connective tissue disease (MCTD) [Hungarian]. Orv Hetil 2002;143:2543-8.

42. Grant KD, Adams LE, Hess EV. Mixed connective tissue disease - a subset with sequential clinical and laboratory features. J Rheumatol 1981;8:587-98.

43. Nimelstein SH, Brody S, McShane D, Holman HR. Mixed connective tissue disease: A subsequent evaluation of the original 25 patients. Medicine 1980;59:239-48.

44. Hasegawa EM, Caleiro MT, Fuller R, Carvalho JF. The frequency of anti-beta 2-glycoprotein I antibodies is low and these antibodies are associated with pulmonary hypertension in mixed connective tissue disease. Lupus 2009;18:618-21.

45. Nishimaki T, Aotsuka S, Kondo H, Yamamoto K, Takasaki Y, Sumiya M, et al. Immunological analysis of pulmonary hypertension in connective tissue diseases. J Rheumatol 1999;26:2357-62.

46. Végh J, Soós G, Csípő I, Demeter N, Ben T, Dezső B, et al. Pulmonary arterial hypertension in mixed connective tissue disease: Successful treatment with iloprost. Rheumatol Int 2006;26:264-9.

47. Jais X, Launay D, Yaici A, Pavec JL, Tchérakian C, Sitbon O, et al. Immunosuppressive therapy in lupus and mixed connective tissue disease-associated pulmonary arterial hypertension. Arthritis Rheum 2008;58:521-31.

48. Yamaguchi T, Ohshima S, Tanaka T, Tsukada S, Matsushita M, Kohmo S, et al. Renal crisis due to intimal hyperplasia in a patient with mixed connective tissue disease (MCTD) accompanied by pulmonary hypertension. Intern Med 2001;40:1250-3.

49. Del Papa N, Sheng YH, Raschi E, Kandiah DA, Tincani A, Khamashta MA, et al. Human beta 2-glycoprotein I binds to endothelial cells through a cluster of lysine residues that are critical for anionic phospholipid binding and offers epitopes for anti-beta 2-glycoprotein I antibodies. J Immunol 1998;160:5572-8.

50. Paice EW, Snaith ML. Thrombotic thrombocytopenic purpura occurring in a patient with mixed connective tissue disease. Rheumatol Int 1984;4:141-2.

51. Kato A, Suzuki Y, Fujigaki Y, Yamamoto T, Yonemura K, Miyajima $\mathrm{H}$, et al. Fatal complication of thrombotic microangiopathy in a patient with mixed connective tissue disease. Rheumatol Int 2002;22:122-5

52. Lin YC, Wu CC, Ou TT, Yen JH, Liu HW, Tsai WC. Malignant thymoma associated with mixed connective tissue disease: a case report. Clin Rheumatol 2006;25:262-4.

53. Fujiwara H, Nakamura D, Kukita T, Hamada H, Ozaki A, Matsushita K, et al. Immunosuppressive treatment for mixed connective tissue disease may facilitate the development of adult $\mathrm{T}$ cell leukemia/lymphoma in a HTLVI carrier. Intern Med 2006;45:297-301.

54. Szekanecz E, Szamosi S, Horvath A, Németh Á, Juhász B, Szántó $\mathrm{J}$, et al. Malignancies associated with systemic sclerosis. Autoimmun Rev 2012;11:852-5.

55. Kiss E, Kovacs L, Szodoray P. Malignancies in systemic lupus erythematosus. Autoimmun Rev 2010;9:195-9. 